\title{
Analysis of Perceptions and Prenatal Medical Records of Black Teens Girls in a São Paulo Hospital
}

\author{
Adelma Pimentel1,2 \\ ${ }^{1}$ Psychology and Psychopathology Development, University of Évora, Évora, Portugual \\ ${ }^{2}$ Federal University of Pará, UFPA, Belém, Brazil \\ Email: adelmapi@ufpa.br
}

Received 19 September 2014; revised 12 November 2014; accepted 5 December 2014

Copyright @ 2014 by author and Scientific Research Publishing Inc.

This work is licensed under the Creative Commons Attribution International License (CC BY). http://creativecommons.org/licenses/by/4.0/

c) (i) Open Access

\section{Abstract}

This paper studied pre-natal black teenager girls in a public hospital in Santos, state of São Paulo, Brazil. We discussed the strategies of the professional staff members, and the conceptions of reproductive and sexual health for teenagers. We noticed, among other things that medical records had not been completely filled, the item color had subdivisions, total lack of familiarity with public policies directed toward the Black population, and some discrete signs of institutional racism. We considered that specific attention to black teens was not given during work as part of a public policy; the lack of medical prevention leads to a referral hospital that does not articulate, on triage, the integral health policy for the Black population, the institutional care and equity.

\section{Keywords}

Pre-Natal, Risk, Black Woman, Teenager, Public Policy

\section{Introduction}

Black teen pregnancy is of particular concern and requires that the three spheres of government consolidate integral care for women's health. To achieve this, basic health care and the units of reference need operate under a philosophy of health articulated on humanization, prevention and respect, to permit a qualified staff to implement the National Policy of Integral Health of the Black Population-PNSIPN, and reflect on relations between race and health. The law on which attention to the black population health is based is: The Racial Equality Statute (LAW no 12.228 of July $20^{\text {th }}$ 2010), specifically Title II, that focus on the Right to Health in Articles $6^{\text {th }}, 7^{\text {th }}$ and $8^{\text {th }}$, and Administrative Rule 992, of May $13^{\text {th }}, 2009$ that establishes the all-encompassing logic in the 
PNSIPN. A set of policies and interventions aim to qualify the universalization, decentralization, and the whole of attention to reproductive and sexual health through intensification of prenatal (Brasil, 2010, 2013; Grisotti \& Patrício, 2006; Cunha, 2009).

During the international debates on reproductive and sexual health in the $20^{\text {th }}$ century, the World Health Organization defined reproductive rights as the decision making on reproduction free of discrimination, coercion, and violence; while sexual rights refer to living experience of the possibilities of non-hetero sexuality (Costa, 2010, Maddaleno, 2000). To include risk pregnancy and dialogue with race/color in the field of reproductive sexual health may improve knowledge of the dynamic of operation of the inequalities and inequities that make the black population more vulnerable (Cunha, 2010). Likewise, integrate the intersectionality category, "to understand the logic and the political consequences of intercrossing of multiple axis of subordination" (Piscitelli, 2008).

In the United States, Kost \& Henshaw (2012) did a survey on pregnancy, childbirth and the number of abortions among teenagers. They find that, even though there has been a decrease in pregnancy for 15 to 19 years old adolescents, the number of pregnancy and abortions continues to be greater among young Black girls. According to the authors, some of the factors that have caused such decrease are the use of contraceptives and sexual activity itself, the change in the racial and ethnic composition of the population, increase of poverty, and changes in the public perception on teenager pregnancy.

Furthermore, in the United States, counselling given to adolescents during their medical visits has been a strategy aimed to reduce the damages that are part of public policies on reproductive and sexual health (Harper, Henderson, Schalet, Becker, Stratton, \& Raine, 2010). The authors did a qualitative study with 31 doctors who assisted low-income young people under risk situation, and they concluded that informing on the use of contraceptives and preservatives, sex abstinence and other forms of demonstration of affection in a relationship may contribute against precocious pregnancy. Perry et al. (2012) describe the results of a study done with 26 adolescents between 15 and 20 years old, in Los Angeles, USA, where, through discussing groups, they evaluated text message services containing information on reproductive health.

Rocca \& Harper (2012) in a research with 602 women between 18 and 29 years old concluded that variables, such as the characteristics of the United States health system, the use of less efficient contraception methods by Black and Latino women showed the ethnic disparities. Jackson states that government assistance and investment in comprehensive sexual education programs is a public policy that schools in the US should adopt to prevent early pregnancy; thus, the author points out that sexual education, birth control added to compulsory alternative programs for teenage mothers developed by the schools will be more effective in the promotion of reproductive health.

In Brazil, intersectorial practices of health, education and family effort provide support to permit that young Black girls overcome the risks, and social and emotional vulnerabilities. Health awareness, as a right, permits that the staffs working at Basic Health Units and Reference Hospitals be impartial, transcend traditional medical practices beyond its biological standpoint, and overcome institutional racism, systematic production of ethnic/ racial racism in institutional processes, manifested through norms, practices and discriminatory behaviors adopted at work on a daily basis as a result from ignorance, lack of attention, prejudices or racial stereotypes. (Administrative Rule n ${ }^{\circ}$ 992, de 13/05/2009; AMNB, 2012).

Some actions have been taken at the Secretaria de Política para as Mulheres (Special Secretariat for Women's Policy) with Secretaria de Políticas de Promoção da Igualdade Racial Special (Secretariat for Policies of Racial Equality Promotion), for example the Programa Pró-equidade de Gênero e Raça (Pro Gender-Equity, Race, and Diversity Program) where companies and public and private organizations that participate have implemented, for 18 months, practices of racial ethnic and gender equality receiving a seal pro equality of gender and race (Brasil, 2013). Costa (2010) have pointed that, in Brazil, programs such as Bolsa Família and the strategy for family healthcare has contributed for the promotion of the Black population health.

The aims of this paper are: 1) present an analysis of data shown on digital medical records in 2012 at the gynecological service of the public hospital; 2) discuss and understand the actions performed by the staff responsible for prenatal care to check if the national health program for the Black population is known and also, if practices of institutional racial behavior have occurred during prenatal procedures for Black teens.

\section{Methodological and Theoretical Route}

This research was done in a public hospital in the Municipality of Santos, SP, reference for Prenatal care of high 
risk pregnancy. After authorization by the Ethics Committee, data collection was started concentrated at the prenatal care of the Gynecology Service (opinion 333,359). The theoretical and methodological approaches articulated, to a feasible extent, studies on gender, institutional racism, and reproductive and sexual health.

We used the techniques of electronic medical record analysis, non-participant observation of medical appointments and interviews with a female medical doctor and a nurse considering that they are both part of the prenatal (PN) care staff (Mccracken, 1988). The data collection done by the author occurred between June and August 2013. We believe that the research will make great contributions on the education and training of Psychologists, Doctors, and Nurses working at the Brazilian Unified Health System-SUS and for policies directed to the health of the Black population, mainly young pregnant girls.

The first stage consisted in a survey of the 2012 files to gather information on pregnant teens assisted during the period: 1) number of medical visits; 2) color; 3) education; 4) historic of sexual and reproductive health.

A significant sample was found, that is 152 cases thus making it possible to integrate quantitative methods into the qualitative approach, through data triangulation, combination of methodologies that permit to enrich the description, explanation and understanding of the material collected (Goldenberg, 2004; Flick, 2009).

Once the data were obtained, we started the qualitative stage: four sessions of non-participant observations of the doctor during the patients' visits as well as observation of the nurses, and medical students and an audio recorded interview. Eventually, we made separate interviews with the doctor and the nurse The questions in the interviews were: 1) skill to perform his/her work; 2) recent courses taken for his/her current job; 3) assistance given to teenager girls; 4) daily demands by the patients; 5) awareness of the Comprehensive Women Health Service Program and The Stork Network; 6) the adhesion of Black teenage girls to Prenatal care; 7) knowledge about assistance to black teenage girls; Awareness of PNSIPN and institutional racism (Bauer \& Gaskell, 2002; Turato, 2005).

As for the data analysis, an analysis was done of the oral reports transformed into texts (Ricoeur, 1983). Some sections of the written interviews were removed to compare the data observed with those found in the medical records. We used Marta for the doctor's name during the presentation of the oral reports. She has been working for 23 years in the area of obstetric pathology. For the nurse, we used the name Margarida. She has worked at the hospital for five years.

\section{Results and Discussions}

The quantitative analysis of medical records showed that one hundred and fifty two (152) women received medical assistance in 2012. The young girls were between the ages of 11 and 20 years, 77 White, 53 Black, and 22 without identification. In regard to the age when pregnancy took place, an analysis was done based on the hypothesis of direct correlation between the girls and their color, using dummy ${ }^{1}$ to represent the categories 'White' and "Black or Brown". We saw that in that sample that, from the statistical point of view, there is no relevant correlation ( $\rho=0.028$ for white girls and $\rho=0.034$ for Blacks or Browns), meaning that we cannot confirm that Black teenagers have higher risk of pregnancy. The ages increased, but color had absolutely no influence on the age when pregnancy took place; thus, age and color do not corroborate risk pregnancy for the women investigated.

Table 1 shows that the number of White women receiving assistance is greater than that of Blacks or Browns (Pardos), suggesting the following points: there was a large number of women whose records were not complete; were the forms filled, either through self-declaration, or following the perception of the employee on duty at that moment? Do the blanks show prejudice in relation to the Black color and may indicate institutional racism? Answering these points permits to feed, with reliable materials, the SUS information system/Ministry of Health which since 1966 has foreboded that health professionals indicate the color of the national public health users in order to define specific health policies for the Black population.

To assess the schooling information shown in the medical records, we used the same parameters employed by The Brazilian Institute of Geography and Statistics-IBGE to add to the classes. The data informed that both middle class Black and White women have similar high school education; however, it is possible to observe that, the Black girls, on item "no education or elementary education only" are more incidents than White girls. If correlation analysis of variables color and schooling, converted into dummy, shows that color, in this sample, is not

\footnotetext{
${ }^{1}$ Dummy, binary or dichotomous variables are artifices that replace a categorical variable for a numeric variable, thus permitting mathematic
} and statistics applications, specially the aggregation of qualitative information into models of statistical regression (Wooldridge, 2008). 
Table 1. Number of people, by color, seen by doctors in a month.

\begin{tabular}{|c|c|c|c|c|c|c|c|}
\hline \multirow{2}{*}{ Month/year } & \multirow{2}{*}{ White } & \multirow{2}{*}{ Black or Brown } & \multirow{2}{*}{ Black } & \multirow{2}{*}{ Brown } & \multirow{2}{*}{ No information } & \multicolumn{2}{|c|}{ Total } \\
\hline & & & & & & Absolute & $\%$ \\
\hline January/12 & 3 & 4 & & 4 & 2 & 9 & $5.92 \%$ \\
\hline February/12 & 9 & 6 & & 6 & 3 & 18 & $11.84 \%$ \\
\hline March/12 & 9 & 9 & & 9 & 2 & 20 & $13.16 \%$ \\
\hline April/12 & & 4 & & 4 & 1 & 5 & $3.29 \%$ \\
\hline May/12 & 9 & 5 & 2 & 3 & & 14 & $9.21 \%$ \\
\hline June/12 & 11 & 10 & 1 & 9 & 2 & 23 & $15.13 \%$ \\
\hline July/12 & 7 & 4 & & 4 & 2 & 13 & $8.55 \%$ \\
\hline August/12 & 4 & 2 & & 2 & 1 & 7 & $4.61 \%$ \\
\hline September/12 & 10 & & & & 2 & 12 & $7.89 \%$ \\
\hline October/12 & 5 & 2 & & 2 & 3 & 10 & $6.58 \%$ \\
\hline November/12 & 4 & 4 & 1 & 3 & 3 & 11 & $7.24 \%$ \\
\hline December/12 & 6 & 3 & 2 & 1 & 1 & 10 & $6.58 \%$ \\
\hline Total & 77 & 53 & 6 & 47 & 22 & 152 & \\
\hline$\%$ & $50.66 \%$ & $34.87 \%$ & $11.32 \%{ }^{*}$ & $88.68 \%{ }^{*}$ & $14.47 \%$ & & \\
\hline
\end{tabular}

*Percentages calculated based on the total number of Black and Brown girls. Source: Field research.

a dimension that explains the number of school years, because it lacks statistical relevance ( $\rho=0.196$ for Whites and $\rho=0.082$ for Blacks or Browns), it is reasonable to think that the medical records were not properly filled and could contain errors (Table 2).

On Table 3, it was possible to show that both Whites and Blacks had Prenatal care, however there were too many incomplete medical records, which leads to an interpretation that there is a gap between reality and the information provided by the health system. Another important situation to receive further attention is the impact of hypertension and assistance in fetal medicine, since both of them exemplify the situation of racial inequality. The correlation analysis of the dummy variables on having or not prenatal assistance with color shows that, statistically, the later does not explain the former ( $\rho=0.003$ for Whites and $\rho=0.007$ for Blacks or Browns).

In relation to the qualitative analysis the doctor expressed her concern for failures in the prenatal medical assistance: When we refuse a patient who has arrived here sent from the medical unit the reason is: because, now, there is counter reference, we have to make a justification to the basic unit explaining why she is no longer considered high risk pregnancy: the unit cannot do the diagnosis survey, why? Sometimes the unit lacks medicine like Destrozol to take tests. Where is the failure? Is it in the system? Or, is it in the Unit? Or, is the doctor who does not know how to order supplies? Or, is the Doctor, who has not updated his/her knowledge on the subject? There are innumerous failures, meanwhile the pregnancy time expires Sometimes the girls arrive here in late pregnancy; meanwhile, they have diabetes and it can no longer be reverted, it is a pathology whose diagnosis was not performed.

On the sexual and reproductive historic of the sample the doctor uses the category bad obstetric history to explain when previous sexual practices provoked sexual pathologies. The data on Table 4 inform that, in absolute numbers and percentages, Black girls have fewer rates of occurrences. This is an element that makes it possible to dispute the stereotypes of hyper sexuality associated to Black women (Cruz, 2004).

On the programs directed toward women's health, Margarida, informs that she knows about Stork Program, as well as, the Policy of Integral Women's Health. As for National Policy of Integral Health of the Black Population-PNSIPN, she warned that there is a need for professional assistance without discrimination, and that policies addressed for women be elaborated by women: We must strive for equality, regardless of race, color or sex.

During observations, we noticed that some issues questioned by the users during their visits to the doctors and nurses is more than a space for monitoring the biological dimension of health, it is an environment to clarify doubts, on the job training and provide orientation for the users. 
Table 2. Education.

\begin{tabular}{|c|c|c|c|c|c|c|c|c|}
\hline \multirow[b]{2}{*}{ Age } & \multicolumn{2}{|c|}{ White } & \multicolumn{2}{|c|}{ Black or Brown } & \multicolumn{2}{|c|}{ Unknown } & \multicolumn{2}{|c|}{ Total } \\
\hline & Abs & $\%$ & Abs & $\%$ & Abs & $\%$ & Abs & $\%$ \\
\hline 1) Unknown & 31 & $40.26 \%$ & 23 & $43.40 \%$ & 22 & $14.47 \%$ & 76 & $50.00 \%$ \\
\hline 2) No education, and unfinished elementary education & 1 & $1.30 \%$ & 4 & $7.55 \%$ & & $0.00 \%$ & 5 & $3.29 \%$ \\
\hline 3) Finished elementary education, unfinished middle school & 17 & $22.08 \%$ & 6 & $11.32 \%$ & & $0.00 \%$ & 23 & $15.13 \%$ \\
\hline 4) Finished high school and unfinished college education & 28 & $36.36 \%$ & 20 & $37.74 \%$ & & $0.00 \%$ & 48 & $31.58 \%$ \\
\hline Total Geral & 77 & $100.00 \%$ & 53 & $100.00 \%$ & 22 & $100.00 \%$ & 152 & $100.00 \%$ \\
\hline$P$ & 0.196 & & 0.082 & & & & & \\
\hline
\end{tabular}

Source: Field research.

\begin{tabular}{|c|c|c|c|c|}
\hline \multirow{2}{*}{ Color } & \multirow{2}{*}{ Total } & \multicolumn{2}{|c|}{ Prenatal } & \multirow{2}{*}{$P$} \\
\hline & & Abs & $\%$ & \\
\hline White & 77 & 74 & $96.10 \%$ & 0.003 \\
\hline Black or Brown & 53 & 51 & $96.23 \%$ & 0.007 \\
\hline Not specified & 22 & 21 & $95.45 \%$ & \\
\hline Total & 152 & 146 & $96.05 \%$ & \\
\hline
\end{tabular}

Source: Field research.

Table 4. Bad obstetric history.

\begin{tabular}{ccccc}
\hline \multirow{2}{*}{ Color } & Total & \multicolumn{2}{c}{ Prenatal } & \multirow{2}{*}{$\boldsymbol{P}$} \\
\cline { 3 - 4 } & & Abs & \% & \\
\hline White & 77 & 23 & $29.87 \%$ & 0.147 \\
Black or Brown & 53 & 10 & $18.87 \%$ & 0.007 \\
Not specified & 22 & 3 & $13.64 \%$ & \\
Total & $\mathbf{1 5 2}$ & $\mathbf{3 6}$ & $\mathbf{2 3 . 6 8 \%}$ & \\
\hline
\end{tabular}

Source: Field research.

\section{Final Considerations}

The staff responsible for pregnant women at public hospital is reduced. When we examined the medical records at the place where the medical records were filled, we observed that race/color was included and that information was not always filled. Color is not required for studies; it is only compulsory when a SUS identification card is issued. It became clear that there was invisibility in the perceptions of the health staff on social, economic and racist determinants that interfered in the health of Black teenage girls assisted by hospital.

The affectivity of interventions during Prenatal occurs only when the health staff understands that Black teenage girls have been subjected to several interposed oppressions: color, sex, poverty, and by intrapsychic tensions originated from development.

The research shows that it is necessary to enhance the structural conditions at work, intensify professional education in cooperation with universities and social movements for further reflections on the subject of health, and reflect with the users about the world they live in as well as the social determinants of the health-illness relation.

Based on the research findings, we ought to examine the possibility of using the suggestion made by Harper et al. (2010), as a strategy that should be used by Doctors during routine medical visits, aiming at prevention of reproductive and sexual health of young women. The same should be used on text messaging service evaluated by Perry (2012). 
To understand institutional racism conceived in the interpersonal and programmatic (Brasil, 2013) and the differences between White and Black women, and among Black women themselves, is important to understand what are these differences and the dimensions of experience, the social relation, the subjectivity, and the identity. (Silva, Hall, \& Woodward, 2013). In the case of Black women, "racism is also multiple, since Black women are equal among themselves”. In other words, each Black woman lives, besides racism, with the vantages and/or disadvantages connected to the different identities they carry (AMNB, 2012: p 17).

The public hospital practices a classic intervention for Prenatal, articulated on the biomedical paradigm where medical hierarchy based on knowledge prevails when providing assistance to the users, and during medical students' training. The health staff is not aware of the existence of National Policy of Integral Health of the Black Population-PNSIPN, although alert for cases of sick cell anemia.

With this research, for example, we hope to contribute to filling the gaps that are indicated by the users: for the training of new doctors, for the apprehension and execution of public policies addressed to the Black population health and also during humanizing interventions. Once they overcome the mismatch between Prenatal routine service, and the evaluation of Black people demands, the health staff may strengthen the hospital social commitment, and "expand the vision of health beyond its biological issues, as well as those of functional individual concerns, referring to factors that act over people's life and working conditions, and groups, that might have some impact over health” (AMNB, 2012: p. 13).

\section{References}

Articulação DE Organizações DE Mulheres Negras Brasileiras (AMNB) (2012). Saúde Da Mulher Negra: Guia Para A Defesa Dos Direitos Das Mulheres Negras. Articulação De Organizações De Mulheres Negras Brasileiras. Porto Alegre.

Bauer, M. W., \& Aarts, B. (2008) A construção do corpus: Um princípio para a coleta de dados qualitativos. In M. W. Bauer, \& G. Gaskell, (Orgs), Pesquisa qualitativa com texto, imagem e som: Um manual prático (7th ed., pp. 39-63). Petrópolis: Vozes.

Bauer, \& Gaskell, Eds. (2002) Pesquisa qualitativa com texto, imagem e som-Um manual prático. Trad.: Pedrinho Guareschi. Petropólis/RJ: Vozes.

Brasil (2010). Estatuto da Igualdade Racial. Lei $n^{0}$ 12.288, 20 de julho. Secretaria de Políticas de Promoção da Igualdade racial. Brasília, $46 \mathrm{p}$.

Brasil (2013). Política Nacional de Saúde Integral da População Negra: Uma politica para o SUS. Ministério da Saúde (2a Ed.). Brasília, 36 p.

Costa, A. M. (2010). Promoção da equidade em saúde para a população negra (Vol. 13, pp. 100-106). Salvador, SUS: Mosaico de Inclusões.

Cruz, I. C. F. da. (2004). A sexualidade, a saúde reprodutiva e a violência contra a mulher negra: Aspectos de interesse para assistência de enfermagem. Revista da Escola de Enfermagem da USP, 38, 448-457. http://dx.doi.org/10.1590/S0080-62342004000400011

Cunha, E. M. G. DE P. (2010). Diferenciais Étnico-Raciais Nas Características Sociodemográficas Da População Paulista. In A. S. Kalckman, L. E., Batista, C. M. DE Castro, T. DI G. DO Lago, \& S. R. DE Souza (Organizadores.), Nascer com equidade: Humanização do parto e do nascimento: Questões raciais/cor e de gênero (pp. 85-100). SP: Instituto da saúde.

Flick, U. (2009) Introdução à pesquisa qualitativa (3rd ed., pp. 32). Tradução J. E. Costa. São Paulo: Artmed.

Goldenberg, M. (2004). A arte de pesquisar: Como fazer pesquisa qualitativa em Ciências Sociais (8th ed., pp. 61-67). Rio de Janeiro: Record.

Grisotti, M., \& Patrício, Z. M. (2006). A saúde coletiva entre discursos e práticas: A participação de usuários, trabalhadores e conselheiros de saúde no município de Florianópolis. Florianópolis: Ed da UFSC.

Harper, C. C., Henderson, J. T., Schalet, A., Becker, D., Stratton, L., \& Raine, T. R. (2010). Abstinence and Teenagers: Prevention Counseling Practices of Health Care Providers Serving High-Risk Patients in the United States. Perspectives on Sexual and Reproductive Health, 42, 125-132. http://dx.doi.org/10.1363/4212510

Kost, K., \& Henshaw, S. (2012). U.S. Teenage Pregnancies, Births and Abortions, 2008: National Trends by Age, Race and Ethnicity. http://www.guttmacher.org/pubs/USTPtrends08.pdf

Mccracken, G. (1988). The Long Interview. Thousand Oaks, CA: Sage.

Maddaleno, M. (2000). Em: Organización Pan-Americana de la Salud. Recomendaciones para la atención integral de salud de los adolescentes con énfasis en salud sexual y reproductiva (Serie OPS/FNUAP, No. 2, pp. 3-5). Washington DC: OPS.

Piscitelli, A. (2008). Interseccionalidades, categorias de articulação e experiências de migrantes brasileiras. São Paulo. 
Sociedade e Cultura, 11, 263-274.

Perry, R. C. W., Kayekjian, K. C., Braun, R. A., Cantu, M., Sheoran, B., \& Chung, P. J. (2012). Adolescents’ Perspectives on the Use of a Text Messaging Service for Preventive Sexual Health Promotion. Journal of Adolescent Health, 51, 220-225. http://dx.doi.org/10.1016/j.jadohealth.2011.11.012

Ricoeur, P. (1983). Interpretação e ideologias. Rio de Janeiro: Francisco Alves.

Rocca, C. H., \& Harper, C. C. (2012). Do Racial and Ethnic Differences in Contraceptive Attitudes and Knowledge Explain Disparities in Method Use? Perspectives on Sexual and Reproductive Health, 44, 150-158. http://dx.doi.org/10.1363/4415012

Silva, T. T. DA, Hall, S., \& Woodward, K. (2013). Identidade e Diferença: A perspectiva dos estudos culturais (133 p). Petrópolos: Vozes.

Turato, E. R. (2005). Qualitative and Quantitative Methods in Health: Definitions, Differences and Research Subjects. Revista de Saúde Pública, 39, 507-514. http://dx.doi.org/10.1590/S0034-89102005000300025

Wooldridge, J. M. (2008) Introdução à econometria: Uma abordagem moderna. São Paulo: Cengage Learning. 
Scientific Research Publishing (SCIRP) is one of the largest Open Access journal publishers. It is currently publishing more than 200 open access, online, peer-reviewed journals covering a wide range of academic disciplines. SCIRP serves the worldwide academic communities and contributes to the progress and application of science with its publication.

Other selected journals from SCIRP are listed as below. Submit your manuscript to us via either submit@scirp.org or Online Submission Portal.
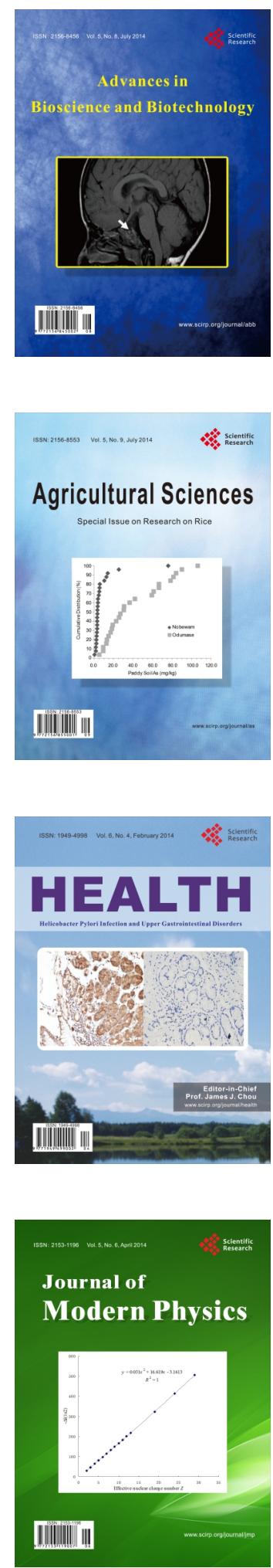
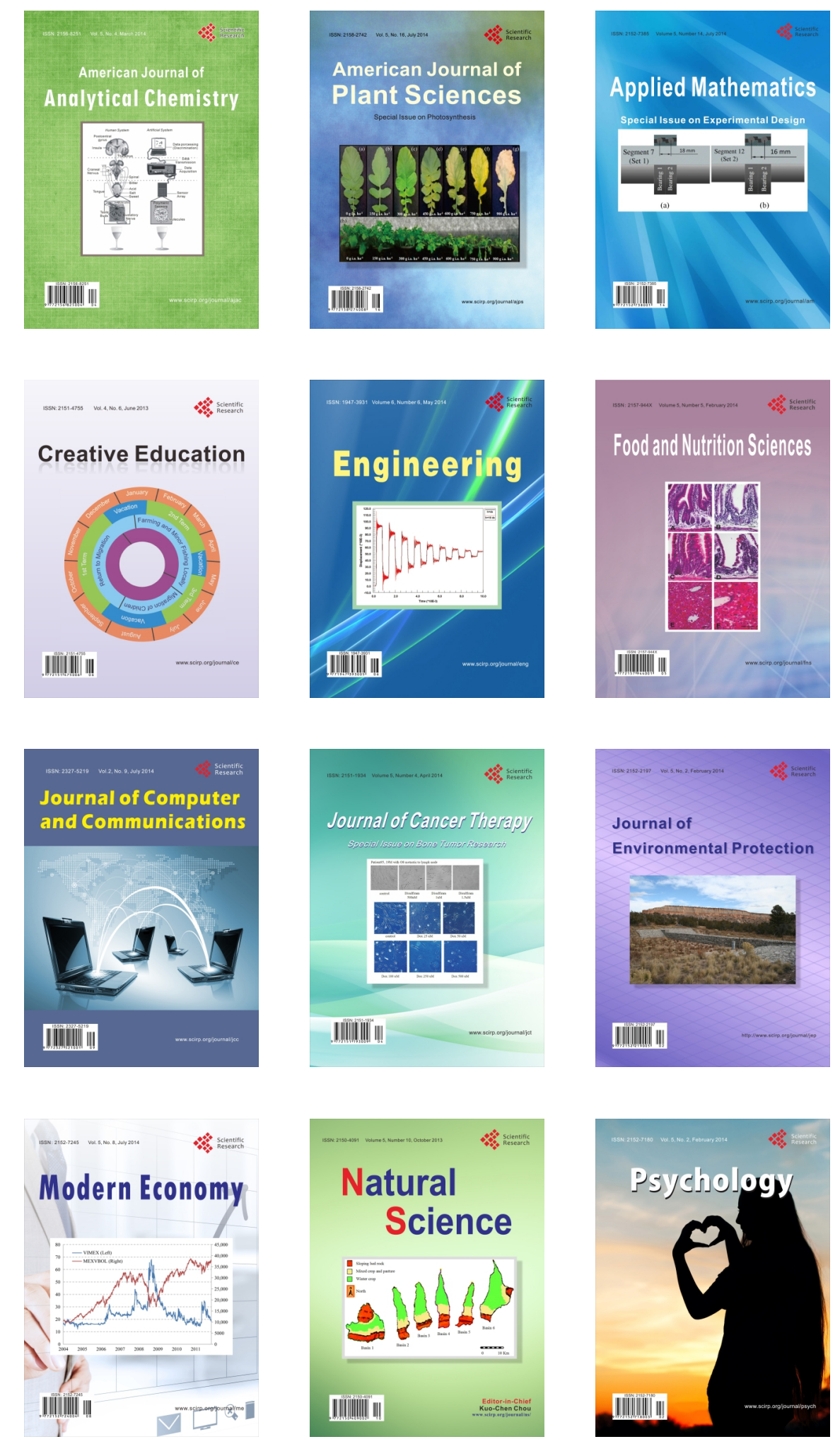